\title{
KIMBERLITES AND CARBONATITES OF THE SNAP LAKE/KING LAKE DYKE SYSTEM: STRUCTURAL SETTING, PETROCHEMISTRY AND PETROLOGY OF A UNIQUE TYPE OF ASSOCIATION.
}

\author{
Pokhilenko N.P. ${ }^{1,2}$, McDonald J.A. ${ }^{1}$, Vavilov M.A. ${ }^{2}$, Agashev A.M. ${ }^{2}$, Clarke D.B. ${ }^{1}$, Wright K-J ${ }^{1}$. \\ ${ }^{I}$ Diamondex Resources Ltd., Vancouver, Canada; ${ }^{2}$ Institute of Mineralogy and Petrography, Novosibirsk, Russia.
}

\section{INTRODUCTION}

The highly diamondiferous Snap Lake/King Lake (SL/KL) kimberlite dyke system, located in the Southern Slave Craton, Northwest Territories, Canada, was discovered by Winspear Resources Ltd. in 1997, and drilled by Diamondex Resources Ltd. in 2001. Initial studies of the unique kimberlite-carbonatite association of the SL/KL dyke system provided results suggesting abnormally thick lithosphere beneath the SL/KL area (Pokhilenko et al., 1998, 2000, 2001; McLean, 2001), and an unusual character of the mantle sources of the SL/KL kimberlite-carbonatite rocks (Agashev et al., 2001, 2002). These results and the unusual geometry of the kimberlite system suggest that the $\mathrm{SL} / \mathrm{KL}$ dyke system represents a new type of large primary diamond deposit.

\section{STRUCTURAL \\ SETTING GEOMETRY}

The SL/KL kimberlite dyke system occupies an area of approximately $4 \mathrm{~km} \times 5.5 \mathrm{~km}$. The main part of the system is located beneath Snap Lake extends northwards to King Lake. The deposit region is situated $\sim 10 \mathrm{~km}$ north of a major fault structure of the southern Slave Craton, the W-SW $\left(250^{\circ}\right)$ trending Lac Capot Blanc Fault. North of this large fault, numerous less-extensive splays and sub-parallel faults occur. One of these, the Snap Lake Fault, is crossed by the SL/KL kimberlite dyke system. The system is comprised of a single main dyke flanked by several narrower gently dipping $\left(8-25^{\circ}\right)$ sub-parallel dykes that are dominated by massive hypabyssal kimberlite. The main kimberlite of the sytem, known as the Northwest (NW) Dyke, averages $3 \mathrm{~m}$ wide and dips gently $\left(9-13^{\circ}\right)$ to the E-NE. The shallowest exposures of the main dyke were found beneath a thin cover of glacial deposits on a small peninsula in the northwestern corner of Snap Lake. While the SL/KL dyke system is dominated by massive hypabyssal kimberlite; kimberlite breccias and carbonatites also occur to lesser extents. The emplacement age of this dyke system has been estimated near $530 \mathrm{Ma}$ (Agashev et al., 2001).

\section{PETROGRAPHY}

Over $80 \%$ of the studied sections of the SL/KL dyke system show massive kimberlite of macrocrystic texture (macrocrystic hypabyssal kimberlite, Mitchell, 1986). The remaining sections include kimberlites of aphyric texture (with very low amount of xenogenic material), carbonate-enriched kimberlites and their breccias, and carbonatites.

Macrocrysts of massive kimberlite are pseudomorphs of serpentine and carbonate after olivine, vary in size from 2 to $30 \mathrm{~mm}$ (predominantly 3 to $15 \mathrm{~mm}$ ), and occurring in variable amounts ranging from 3 to 40 vol.\%. The massive kimberlite groundmass minerals include serpentine, phlogopite (often significantly replaced by chlorite), carbonates, and opaque minerals. Phlogopite is an important component of the groundmass, comprising 1 to $25 \mathrm{vol} . \%$ of the total groundmass; thus significant portions of the SL/KL kimberlite dykes belong to the mica-enriched varieties. The other mineral contents of the studied kimberlites groundmass vary significantly. The amount of opaque minerals, mainly spinelides of variable composition, can reach up to $15-20$ vol.\% of the groundmass, although in some samples they are minor components of groundmass $(<0.1$ vol.\%). Relatively rare xenoliths occur as irregular fragments of granitoid and metamorphic rocks and more rarely as rounded xenoliths of low crust and upper mantle rocks. Xenoliths of "kimberlite in kimberlite" (autoliths) are very rare. Carbonate-rich kimberlites and carbonatites, despite their limited distribution in the SL/KL kimberlite dyke system, are characterized by wide variations in their mineral composition and textural-structural peculiarities. Carbonate-rich kimberlites and carbonatites both show a nearly complete absence of porphyritic grains. 


\section{PETROCHEMISTRY}

The SL/KL kimberlite dyke system rock compositions range widely, with some representative analyses presented in Table 1 (Fig. 1). The most carbonatedepleted kimberlite contains up to 37 wt. $\% \mathrm{SiO}_{2}, \mathrm{MgO}$ to $35 \mathrm{wt} . \%, \mathrm{CaO}$ as little as $1.5 \mathrm{wt} . \%$ and carbonatites (mainly dolomite) as little as 3.5 wt.\% $\mathrm{SiO}_{2} \cdot \mathrm{TiO}_{2}$ content ranges from $0.18 \mathrm{wt} \%$ in the most carbonate enriched rocks to 0.93 wt.\% in low-Ca, $\mathrm{K}_{2} \mathrm{O}$-enriched (up to 2.16 wt.\%) kimberlites. The correlation between $\mathrm{TiO}_{2}$ and $\mathrm{K}_{2} \mathrm{O}$ suggests that this kimberlite is intermediate between kimberlite and "orangeites"(Mitchell, 1995) but with a visible tendency to more closely approximate the latter (Fig. 1). Of special interest is rare variety of high-Ca kimberlite with unusually high $\mathrm{P}_{2} \mathrm{O}_{5}$ content - up to 6.74 wt.\% (Table 1; Sample 7) that is extraordinary for kimberlites.

Table 1. Representative analyses of SL/KL kimberlites (1-5, 7) and carbonatite (6).

\begin{tabular}{lllll} 
Sample & 1 & 2 & 3 & 4 \\
\hline $\mathrm{SiO} 2$ & 35.6 & 34.8 & 33.4 & 26.8 \\
$\mathrm{TiO} 2$ & 0.76 & 0.88 & 0.69 & 0.52 \\
$\mathrm{Al} 2 \mathrm{O} 3$ & 3.14 & 3.60 & 3.43 & 2.06 \\
$\mathrm{Fe} 2 \mathrm{O} 3$ & 8.64 & 8.95 & 8.05 & 6.09 \\
$\mathrm{MnO}$ & 0.15 & 0.16 & 0.16 & 0.17 \\
$\mathrm{MgO}$ & 34.7 & 30.8 & 32.1 & 25.2 \\
$\mathrm{CaO}$ & 1.80 & 3.87 & 6.05 & 12.4 \\
$\mathrm{Na} 2 \mathrm{O}$ & 0.01 & 0.01 & 0.01 & 0.01 \\
$\mathrm{~K} 2 \mathrm{O}$ & 1.07 & 1.62 & 2.16 & 0.88 \\
$\mathrm{P} 2 \mathrm{O} 5$ & 0.33 & 0.80 & 0.56 & 0.20 \\
$\mathrm{LOI}$ & 13.7 & 14.5 & 13.4 & 25.7 \\
$\mathrm{Total}$ & 99.9 & 100.0 & 100.1 & 100.0 \\
& & & & \\
$\mathrm{Sample}$ & 5 & \multicolumn{2}{c}{6} & 7 \\
\hline $\mathrm{SiO} 2$ & 23.6 & & 13.5 & 20.3 \\
$\mathrm{TiO} 2$ & 0.33 & \multicolumn{2}{c}{0.67} & 0.18 \\
$\mathrm{Al} 2 \mathrm{O} 3$ & 1.60 & \multicolumn{2}{c}{3.19} & 1.84 \\
$\mathrm{Fe} 2 \mathrm{O} 3$ & 6.30 & \multicolumn{2}{c}{9.58} & 5.48 \\
$\mathrm{MnO}$ & 0.22 & & 0.25 & 0.16 \\
$\mathrm{MgO}$ & 20.3 & 21.1 & 21.2 \\
$\mathrm{CaO}$ & 20.6 & & 16.5 & 20.7 \\
$\mathrm{Na} 2 \mathrm{O}$ & 0.01 & \multicolumn{2}{c}{0.01} & 0.01 \\
$\mathrm{~K} 2 \mathrm{O}$ & 0.42 & 0.79 & 0.50 \\
$\mathrm{P} 2 \mathrm{O} 5$ & 1.49 & 0.36 & 6.74 \\
$\mathrm{LOI}$ & 24.9 & 34.9 & 21.9 \\
$\mathrm{Total}$ & 99.8 & 100.8 & 99.0
\end{tabular}

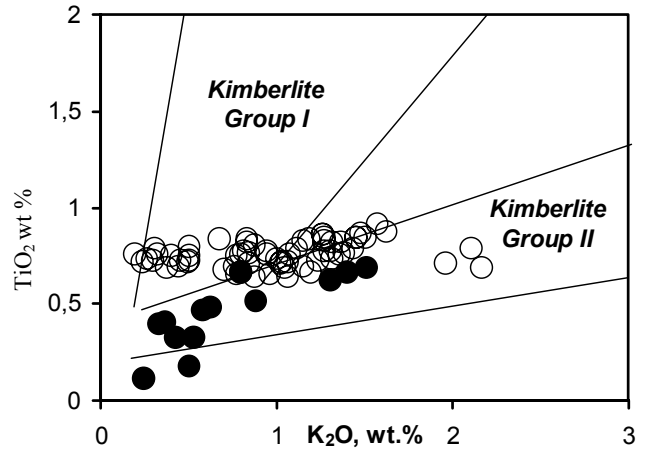

Figure 1: $\mathrm{Plot} \mathrm{TiO}_{2}$ vs $\mathrm{K}_{2} \mathrm{O}$ for $\mathrm{SL} / \mathrm{KL}$ kimberlite composition (solid dots - carbonatites and carbonate-rich kimberlites; open dots - low-carbonate kimberlites).

\section{MINERALOGY}

\section{OLIVINE}

Kimberlite with fresh olivine was found in the northern part of the SL/KL dyke system (King Lake area), at subsurface depths of over $1.5 \mathrm{~km}$. Samples from one thin intersection contained unaltered olivine microphenocrysts less than $0.1 \mathrm{~mm}$ in size, and some of them were zoned. The zoning occurs as follows (Fig. 2): $\mathrm{Mg} \#$ (normal): 92.2 to 90.1$) ; \mathrm{Mg} \#$ (reversed): 87.5 to 91.4; $\mathrm{Cr}_{2} \mathrm{O}_{3}:<0.01$ to 0.16 wt.\%; $\mathrm{MnO}: 0.10$ to 0.23 wt.\%; $\mathrm{NiO}$ (normal): 0.36 to 0.07 wt.\% and (reversed): 0.19 to 0.35 wt. $\%$; $\mathrm{CaO}$ (normal): 0.02 to 0.10 wt. $\%$, (reversed) 0.05 to $0.02 \mathrm{wt} \% \%$ and (complex): $0.04-0.02-$ 0.05 wt.\%). In relatively fresh hypabyssal kimberlite, 78 analyses of olivine macrocrysts demonstrated a range in $\mathrm{Mg} \#$ between 87.5 and 93.4 with a mean of



Figure 2: Plots of $\mathrm{NiO}$ vs $\mathrm{FeO}$ for (a) olivines of $\mathrm{SL} / \mathrm{KL}$ kimberlite and for (b) zoned olivine microphenocrysts of the SL/KL kimberlite groundmass. 
91.2 (Fig. 2). The $\mathrm{NiO}$ component ranges from 0.18 to 0.42 wt. $\%$, with a mean of 0.35 wt. $\%$.

\section{CARBonates}

Carbonates in the groundmass of fresh kimberlite are predominantly dolomite and calcite (Fig. 3). The dolomite shows $\mathrm{FeO}$ content (1.0 to 6.9 wt. \%) that is negatively correlated with $\mathrm{SrO}$ content (0.07-0.94 wt.\%), and calcite (Table 2) contains admixed SrO (up to 5.7 wt.\%) and $\mathrm{BaO}$ (up to 1.6 wt.\%). Other carbonate grains include $\mathrm{Ca}-\mathrm{Sr}$ carbonates with an $\mathrm{SrO}$ content of up to $23.8 \mathrm{wt} . \%$ (Table 2). Rare barite (with minor $\mathrm{FeO}$ ) grains also occur in the groundmass (Table 1, sample 5).

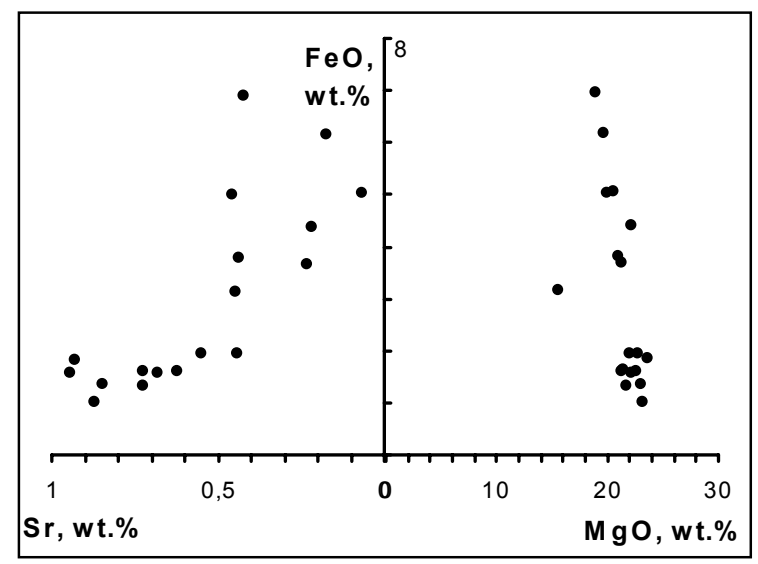

Figure 3: $\mathrm{Plot} \mathrm{SrO}$ vs $\mathrm{FeO}$ vs $\mathrm{MgO}$ for dolomites of $\mathrm{SL} / \mathrm{KL}$ fresh kimberlite groundmass.

\section{Table 2. Representative analyses of carbonates from the SKL kimberlite groundmass.}

\begin{tabular}{llllll} 
Sample & 1 & 2 & 3 & 4 & 5 \\
\hline $\mathrm{FeO}$ & 1.60 & 6.15 & 0.63 & 0.59 & 0.17 \\
$\mathrm{MnO}$ & 0.58 & 0.29 & 0.50 & 0.21 & 0.01 \\
$\mathrm{MgO}$ & 21.2 & 19.6 & 0.32 & 1.62 & 0.03 \\
$\mathrm{CaO}$ & 28.6 & 30.5 & 55.7 & 28.3 & 0.01 \\
$\mathrm{BaO}$ & 0.01 & 0.01 & 0.01 & 5.51 & 62.0 \\
$\mathrm{SrO}$ & 0.94 & 0.18 & 0.91 & 23.8 & 0.03 \\
Total & 52.9 & 56.7 & 58.1 & 60.0 & 62.2
\end{tabular}

\section{PHLOGOPITE}

Phlogopites of the SL/KL kimberlite groundmass are characterized by variations in $\mathrm{F}$ content $(<0.10$ to 1.46 wt. $\%) ; \mathrm{TiO}_{2}$ content ( 0.32 to 4.99 wt. $\%$, predominantly between 0.8 and 2.0 wt. $\%$ ); $\mathrm{Cr}_{2} \mathrm{O}_{3}$ content ( 0.01 to 2.85 wt.\%), and extremely variable $\mathrm{BaO}$ content ( 0.1 to 9.3 wt.\%). A wide variation in $\mathrm{Al}_{2} \mathrm{O}_{3}$ content (11.8 to 19.6 wt.\%) is shown in Figure $4 \mathrm{a}$, where the presence of at least three separate clusters inside the kimberlite groundmass micas field is visible (field position after R.H.Mitchell, 1995). Of note, is the absence of the fresh kimberlite groundmass micas (open circles) in the central group of phlogopites (those with moderate $\mathrm{Al}_{2} \mathrm{O}_{3}$ content and relatively low $\mathrm{TiO}_{2}$ ) (Fig. 4a). These phlogopites are characterized by minimal $\mathrm{Ba}$ and maximal $\mathrm{K}$ contents when compared with compositions of the groundmass phlogopites of the main (NW) dyke of the SL/KL system (Fig. 4b).
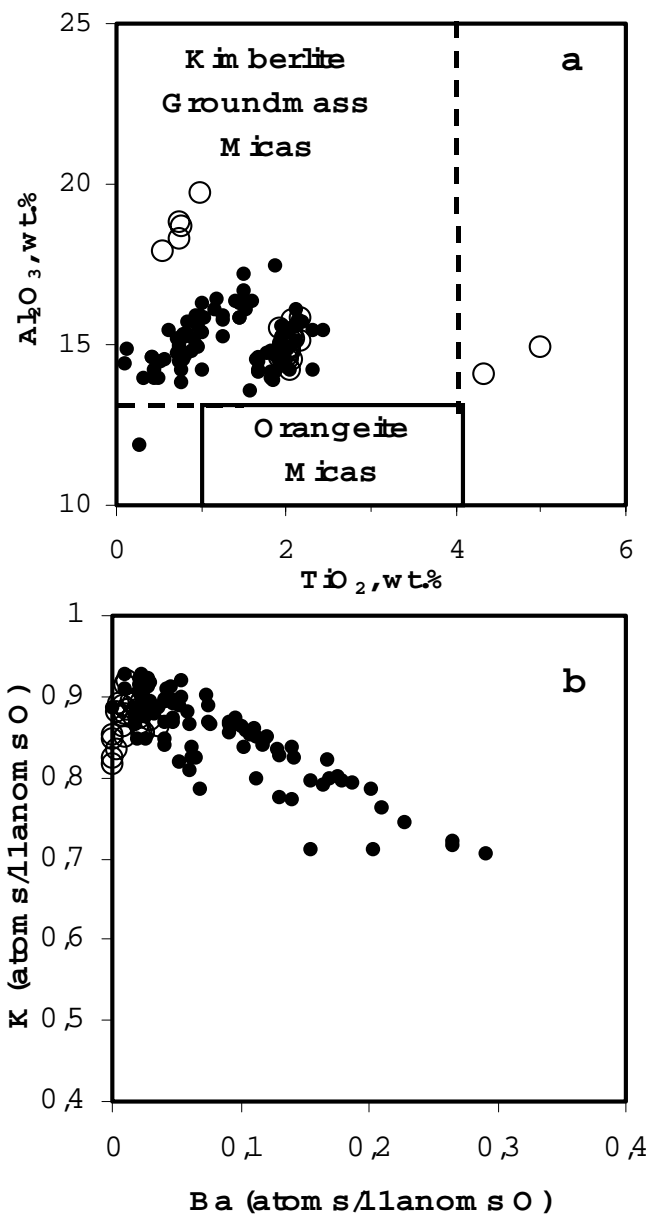

Figure 4: Plots (a) $\mathrm{Al}_{2} \mathrm{O}_{3}$ vs $\mathrm{TiO}_{2}$ and (b) $\mathrm{K}$ vs $\mathrm{Ba}$ (atomic) for $\mathrm{SL} / \mathrm{KL}$ fresh kimberlite groundmass (open dots phlogopites from extremely fresh kimberlite with fresh olivine microphenocrysts; solid dots - from all other SL/KL kimberlites). 


\section{OPAQUe Minerals}

Dominant opaque minerals of the SL/KL kimberlite are spinelides of two groups: (1) Cr-spinels with less than 30 mol.\% magnetite + ulvospinel; and (2) Al-Cr-Mg-Ti magnetites of relatively uniform composition. Rutile and sulphides also occur in the kimberlite groundmass.

\section{INDICATOR MINERALS}

Indicator mineral abundance in this kimberlite is low. Indicator minerals comprise: a) Garnets: garnet content is $\sim 150-200 \mathrm{~g} / \mathrm{t}$ of kimberlite; $\sim 96 \%$ of them are $\mathrm{Cr}-$ pyropes with wide ranges of $\mathrm{Cr}_{2} \mathrm{O}_{3}$ content $(0.1-17.0$ wt.\%), with a relatively low proportion of G10 garnets (Pokhilenko et al., 1998, 2000). The remaining 4\% are E-type garnets; b) Chromites: chromite content is $100-150 \mathrm{~g} / \mathrm{t}$ of kimberlite, There is a high proportion $(25-27 \%)$ of high-Cr $\left(>62\right.$ wt.\% $\left.\mathrm{Cr}_{2} \mathrm{O}_{3}\right)$ and low-Ti $\left(<0.7\right.$ wt.\% $\left.\mathrm{TiO}_{2}\right)$ varieties present; and (c) $\mathrm{Cr}$ diopsides: Cr-diopside grains are very rare. No grains of Mg-ilmenite were found in the studied samples.

\section{DISCUSSION}

The SL/KL kimberlites show a range of geochemical characteristics that differentiate them from both Group I and Group II kimberlites (Agashev et al., 2001, 2002). The SL/KL kimberlites show REE distribution and isotopic characteristics similar to Group I kimberlites. However, abundances of the most incompatible elements $(\mathrm{Pb}, \mathrm{Rb}, \mathrm{La}, \mathrm{Ce})$ are intermediate between Group I and II kimberlites, and $\mathrm{Ba}$ and Th abundances more closely resemble Group II kimberlites. Relative to $\mathrm{SL} / \mathrm{KL}$ kimberlites, trace element abundances of carbonatites associated with these kimberlites are depleted in $\mathrm{Cs}, \mathrm{Rb}, \mathrm{K}, \mathrm{Ta}$, Ti and enriched in $\mathrm{U}, \mathrm{Sr}, \mathrm{P}$, $\mathrm{Zr}$, Hf, MREEs and HREEs. Trace element partitioning between kimberlite and carbonatite of the SL/KL dyke system contrasts with experimental partitioning data within immiscible carbonate and silicate liquids, where the carbonatite shows preferential partitioning of HREE, $\mathrm{Y}$ and $\mathrm{Zr}$ into silicate liquid, and $\mathrm{Rb}, \mathrm{K}$, and $\mathrm{Ba}$ are preferentially enriched in the carbonate-rich liquid.

The most likely mantle source for the SL/KL kimberlite-carbonatite association is slightly carbonated (0.5-0.6 vol.\% of carbonate) depleted Cr-pyrope lherzolite. Partial melting (0.5-2.5 \%) of these rocks at pressures over $70 \mathrm{kbar}$ can produce the range of kimberlite-carbonatite melts observed in the SL/KL association. The $\mathrm{Nb} / \mathrm{Ta}$ ratio in $\mathrm{SL} / \mathrm{KL}$ carbonatites ranges from slightly superchondritic $(\mathrm{Nb} / \mathrm{Ta}=22$ at $\mathrm{SiO}_{2}=17$ wt.\%) to highly superchondritic $(\mathrm{Nb} / \mathrm{Ta}=81$ at $\mathrm{SiO}_{2}=3.7 \mathrm{wt} . \%$ ). By contrast, the ratio in $\mathrm{SL} / \mathrm{KL}$ kimberlites scatters around the chondritic value of 18 . This suggests that the initial partial melt of the carbonated lherzolite source was carbonatic and possessed superchondritic $\mathrm{Nb} / \mathrm{Ta}$ and $\mathrm{Zr} / \mathrm{Hf}$ ratios.

Some of the petrological and petrochemical characteristics described above are also of intermediate values between kimberlites of Group I and II. For example, combined variations of $\mathrm{K}_{2} \mathrm{O}$ and $\mathrm{TiO}_{2}$ contents are close to those of kimberlites of Group II, and the mica-enriched texture of the groundmass in significant parts of the SL/KL kimberlites are also similar to those of Group II kimberlites. However, the $\mathrm{SL} / \mathrm{KL}$ kimberlite groundmass mica composition is different from Group II ("orangeite") micas (Mitchell, 1995) and closer to that of Group I kimberlite (Fig. 4). Many other petrochemical and petrographic features of SKL kimberlites are close for kimberlites of Group I. These results demonstrate some of the unique characteristics of the SL/KL kimberlite- carbonatite association.

\section{REFERENCES}

Agashev, A.M., Pokhilenko, N.P., McDonald, J.A., Takazawa, E., Vavilov, M.A., Sobolev, N.V., and Watanabe, T. (2001) A unique kimberlitecarbonatite primary association in the Snap Lake dyke system, Slave Craton: evidence from geochemical and isotopic studies. SlaveKaapvaal Workshop, Merrickville, Ontario, Canada.

Agashev, A.M., Pokhilenko, N.P., Takazawa, E., Watanabe, T., McDonald, J.A., Sobolev, N.V., Vavilov, M.A., and Fomin, A.S. (2002) Do superchondritic $\mathrm{Nb} / \mathrm{Ta}$ ratios in kimberlites tell the lower mantle plume signature? Superplume International Workshop, Tokyo, Japan, 244245.

McLean, R.C., Pokhilenko, N.P., Hall, A.E., Luth, R. (2001) Pyropes and chromites from kimberlites of the Snap Lake area, Southeast Slave Craton: garnetization reaction of depleted peridotites at extremely deep levels of the lithospheric mantle. Slave-Kaapvaal Workshop, Merrickville, Ontario, Canada.

Mitchell,,R.H. (1986) Kimberlites: Mineralogy, Geochemistry, and Petrology. Plenum Press, New York.

Mitchell, R.H. (1995) Kimberlites, Orangeites, and Related Rocks. Plenum Press, New York and London.

Pokhilenko, N.P., McDonald, J.A., Melnyk, W., Hall, A.E., Shimizu, N., Vavilov, M.A., Afanasiev, V.P., Reimers, L.F., Irvin, J., Pokhilenko, L.N., Vasilenko, V.B., Kuligin, S.S., and Sobolev, N.V. (1998) Kimbrlites of Camsell Lake field and some features of structure and composition 
of lithosphere roots of southeastern pert of Slave Craton, Canada. Extended Abstracts $7^{\text {th }}$ International Kimberlite Conference, Cape Town, pp. 699-701.

Pokhilenko, N.P., Sobolev N.V., Tcherny S.D., Mityukhin S.I., and Yanygin Yu.T. (2000) Pyropes and chromites from kimberlites of Nakyn Field (Yakutia) and Snap Lake area (Slave Province, Canada): evidence of anomalous lithosphere structure. Doklady Akademii Nauk, v. 372, 3, 356-360 (in Russian).

Pokhilenko, N.P., Sobolev, N.V., McDonald, J.A., Hall, A.E., Yefimova, E.S., Zedgenizov, D.A., and Logviniva, A.M. (2001) Crystalline inclusions in diamonds from kimberlites of the Snap Lake area (Slave Craton, Canada): new evidence of anomalous lithosphere structure. Doklady Akademii Nauk, 380(3), 374-379 (in Russian).

Contact: JA McDonald, Diamondex Resources Ltd, 1410-650 West Georgia St, Vancouver, BC Canada V6B 4N8 E-Mail: jmcdonald@diamondex.net 